\title{
Sponge-associated fungi and their bioactive compounds: the Suberites case
}

\author{
Peter Proksch ${ }^{1, *}$, Rainer Ebel',a, RuAngelie \\ Edrada1, Frank Riebe'1, Hongbing Liu'1, Arnulf \\ Diesel', Mirko Bayer', Xiang Li², Wen Han Lin², \\ Vladislav Grebenyuk ${ }^{3}$, Werner E.G. Müller ${ }^{3}$, \\ Siegfried Draeger ${ }^{4}$, Alga Zuccaro 4 and \\ Barbara Schulz ${ }^{4}$ \\ ${ }^{1}$ Institut für Pharmazeutische Biologie und \\ Biotechnologie, Heinrich-Heine-Universität Düsseldorf, \\ Universitätsstr. 1, Geb. 26.23, 40225 Düsseldorf, \\ Germany, e-mail: proksch@uni-duesseldorf.de \\ ${ }^{2}$ National Research Laboratory of Natural and \\ Biomimetic Drugs, Peking University, 100083 Beijing, \\ P.R. China \\ ${ }^{3}$ Institut für Physiologische Chemie und \\ Pathobiochemie, Johannes-Gutenberg-Universität, \\ Duesbergweg 6, 55128 Mainz, Germany \\ ${ }^{4}$ Institut für Mikrobiologie, Technische Universität \\ Carolo-Wilhelmina zu Braunschweig, Spielmannstraße \\ 7, 38106 Braunschweig, Germany \\ * Corresponding author
}

\begin{abstract}
Specimens of Suberites domuncula that had been cultured in aquaria for 4 weeks were analyzed for their associated fungi. A total of 81 fungal strains belonging to 20 different genera was isolated and identified by morphological and molecular methods. The most frequently isolated taxa were Cladosporium spp., Penicillium spp., Petriella sp., Phialophora spp. and Engyodontium album. Based on chromatographic and mass spectrometric analysis of fungal extracts, as well as on bioassay results, Aspergillus ustus, Penicillium sp., Petriella sp. and Scopulariopsis sp. were selected for in-depth analysis of their natural products. A total of 19 different fungal metabolites, including three new natural products, was isolated and structurally identified. $A$. ustus yielded two sesquiterpenes, a drimane derivative and deoxyuvidin, as well as a sesterterpene ophiobolin $\mathrm{H}$. The drimane derivative had an $E_{50}$ value against L5178Y cells of $1.9 \mu \mathrm{g} \mathrm{ml}^{-1}$ in vitro. The crude extract of Petriella sp. was also strongly cytotoxic against the L5178Y cell line. The cyclic tetrapeptide WF-3161 was primarily responsible for the activity; the $\mathrm{ED}_{50}$ value was $<0.1 \mu \mathrm{g} \mathrm{ml}^{-1}$. It was identical to the known compound WF-3161 and had been previously isolated from Petriella guttulata. In addition to WF-3161, three further natural products were obtained and unequivocally identified as new derivatives of infectopyrone by one- and two-dimensional NMR spectroscopy and by

\footnotetext{
a Present address: Department of Chemistry, University of Aberdeen, Meston Building, Meston Walk, Old Aberdeen, AB24 3UE Scotland, UK.
}

mass spectroscopy. Of the new compounds, only dihydroinfectopyrone was active against L5178Y cells; the $\mathrm{ED}_{50}$ value was $0.2 \mu \mathrm{g} \mathrm{ml}^{-1}$. Penicillium $\mathrm{sp}$. yielded the largest number of metabolites. Viridicatin, viridicatol, cyclopenin and cyclopenol suppressed larval growth of the polyphagous pest insect Spodoptera littoralis when incorporated into an artificial diet at an arbitrarily chosen concentration of $237 \mathrm{ppm}$. Viridicatol was the most active compound and had an $\mathrm{ED}_{50}$ value of ca. $50 \mathrm{ppm}$. Scopulariopsis sp. yielded three metabolites, including the known acetylcholinesterase inhibitors quinolactacin A1 and $\mathrm{A} 2$.

Keywords: marine natural products; sponge-associated fungal metabolites; Suberites domuncula.

\section{Introduction}

In the last decade, marine microorganisms, such as bacteria, microalgae and fungi, have become increasingly important as sources for new bioactive natural products (Ebel 2006, König et al. 2006, Laatsch 2006, Ramaswamy et al. 2006, Shimizu and Li 2006). Fungi have proven to be particularly prolific sources of new compounds when compared to other microbial sources isolated from the sea. The first report of a bioactive natural product from a marine-derived fungus dates back to the 1940s when the fungus Acremonium chrysogenum Gams 1971 was isolated from a sewage outlet in the Mediterranean Sea close to the island of Sardinia. The fungus was the source of cephalosporin $\mathrm{C}$, the parent compound of modern cephalosporin antibiotics that are indispensible for the treatment of numerous bacterial infections (Abraham and Loder 1972). Initially, progress with rigorous evaluation of marine fungal metabolites was slow. This situation changed dramatically in the 1990s when there was a sharp rise in interest in marine microbial metabolites that continues until today. Up to the year 2002, 272 new natural products had been isolated from marinederived fungi (Bugni and Ireland 2004). A dramatic increase in the number of elucidated marine fungal structures began afterwards, illustrated by the fact that between 2002 and 2004, 240 additional compounds were described (Ebel 2006).

Even though the value of marine-derived fungi as a source of new bioactive metabolites is now commonly accepted, there is still much debate on the nature of fungi that are isolated from various marine substrates, such as drifting wood, algae or invertebrates. Due to the fact that numerous, if not most, of these fungi belong to genera already well known from the terrestrial environment, such as Aspergillus, Penicillium, Cladosporium, Phoma, and Fusarium, a true marine origin of these fungal strains is frequently doubted (Höller et al. 2000, Kohlmeyer and 
Volkmann-Kohlmeyer 2003). It is possible that several, if not many, marine-derived fungi thus far investigated originated from terrestrial habitats (e.g., soil) from which they were washed to the sea and survived (as spores) until they were recovered by a marine chemist looking for new compounds from the sea. On the other hand, in the last few years more and more evidence has accumulated indicating an adaptation of these "ubiquitous" fungi to the marine environment (Geiser et al. 1998a,b, Alker et al. 2001, Duncan et al. 2002, Zuccaro et al. 2004). Nevertheless, the fact remains that regardless of their true origin, marine-derived fungi have developed into an important source of new and structurally unprecedented metabolites (Ebel 2006).

Interestingly, sponges continue to be one of the most important sources for the isolation of metabolite-producing marine-derived fungi (Höller et al. 2000, Jensen and Fenical 2002, Bugni and Ireland 2004, Ebel 2006), even though the presence of fungal mycelia growing in sponges has not yet been proven. In contrast to spongederived natural products, such as jaspaklinolide L, theopederin $\mathrm{C}$, or mycalamide $\mathrm{A}$, that bear obvious structural resemblances to known bacterial metabolites (Proksch et al. 2002, Butzke and Piel 2006) and are assumed to originate from bacterial sponge symbionts, there are no examples of known fungal metabolites that have been isolated from sponges. On the other hand, the sponge Suberitis domuncula (Olivi 1792) has receptor proteins for fungal cell wall components, e.g., $(1 \rightarrow 3)-\beta-$ D-glucan, providing evidence that at some time in its life cycle (or in its evolutionary history) the sponge, if not colonized by, at least deals (or dealt) with fungi (PerovićOttstadt et al. 2004). The presence of the $(1 \rightarrow 3)-\beta-D-$ glucan receptor protein in $S$. domuncula, as well as the fact that sponges of this species can be easily maintained in aquaria over several months to a year were decisive in choosing $S$. domuncula as a model organism for our study.

For the time being, the true nature of sponge-fungal associations remains obscure and far more research needs to be devoted to this field. The study presented here is part of a larger project aimed at obtaining a broader picture and a better understanding of the fungal association with sponges using molecular, biochemical and culturing techniques. After screening 81 fungal strains isolated from the sponge Suberitis domuncula (Porifera, Demospongiae, Hadromerida), four isolates were selected for the characterization of active secondary metabolites that may play important roles in situ.

\section{Materials and methods}

\section{General experimental procedures}

${ }^{1} \mathrm{H} N M R$ and ${ }^{13} \mathrm{C}$ NMR, COSY, HMQC and HMBC spectra (chemical shifts in ppm, referenced to residual solvent signals) were recorded on a Bruker ARX-400, DRX 500 or DMX 600 spectrometer (Bruker Daltonik GmbH, Bremen, Germany). For spectral simulation, the MestReC software package (version 4.9.9.9) was used (Mestrelab Research, Santiago de Compostela, Spain). Mass spectra were obtained on Thermofinnigan LCQ Deca (ESI) and
Micromass Q-Tof 2 (HRESIMS) mass spectrometers. For HPLC analysis, samples were injected into a HPLC system coupled to a photodiode-array detector (Dionex, Munich, Germany). Routine detection was at $254 \mathrm{~nm}$ in aqueous $\mathrm{MeOH}$. The separation column $(125 \times 4 \mathrm{~mm}$, i.d.) was a Eurospher-100-C18 reverse phase column (Knauer, Berlin, Germany). Optical rotations were recorded on a Perkin-Elmer-241 MC polarimeter. Semi-preparative HPLC was performed on a Eurospher-100-C18 reverse phase column utilizing a Merck-Hitachi L-7100 pump and L-7400 UV detector.

Solvents were distilled before use and spectral grade solvents were used for spectroscopic measurements. Thin layer chromatography (TLC) was performed on plates precoated with Si 60 F254 (Merck, Darmstadt, Germany). Compounds were detected from their UV absorbance $\left(\lambda_{\max } 235-340 \mathrm{~nm}\right)$ and also by spraying the TLC plates with anisaldehyde reagent.

\section{Isolation and identification of the fungal strains}

Specimens of the marine sponge Suberitis domuncula (Porifera, Demospongiae, Hadromerida) were collected in the Northern Adriatic Sea near Rovinj (Croatia), and then kept in aquaria in Mainz (Germany) for 4 weeks at $17^{\circ} \mathrm{C}$ as previously described (LePennec et al. 2003). In brief, the $\mathrm{pH}$ of artificial seawater (Tropic Marine Centre Ltd., Rickmansworth, UK) was adjusted to 8.0. The sponges, maintained in 200 I aquaria, were fed every second day with $5 \mathrm{ml}$ of Coraliquid, a fluid plankton-based nutrition (Sera; Heinsberg-Dohse Aquaristik, Bonn, Germany) and with $20 \mathrm{ml}$ of "Mainvit-plus", containing strontium, molybdate, lithium, rubidium and iodine (Sera, Heinsberg, Germany). Every other day, $5 \mathrm{~g}$ of deep-frozen Artemia salina (Hundt, Wuppertal, Germany) were added for the hermit crab.

Because stringent surface sterilization procedures had previously proven to be too rigorous for delicate sponge tissues (Höller et al. 2000), sponges were either briefly sterilized for $30 \mathrm{~s}$ in $70 \% \mathrm{v} / \mathrm{v}$ ethanol followed by three subsequent washings in sterile commercial seawater or merely washed three times with sterile seawater. The sponge tissue was then cut into approximately $1.5 \times 1.5 \mathrm{~mm}$ segments and plated on carrot-potato agar growth medium (Höller et al. 2000) with and without artificial sea salts and cultivated at $22^{\circ} \mathrm{C}$. Emerging fungal mycelia were isolated and taken into culture. The identities of sporulating isolates were determined to at least the genus level according to morphology. In cases in which morphological identification was uncertain, molecular identification was undertaken.

\section{DNA extraction and PCR amplification}

DNA was isolated from strains 8009, 7961, 7979 and 8017 using the ultra clean soil DNA isolation kit (Mo Bio Laboratories Inc., Carlsbad, CA, USA) or using the DNeasy Blood \& Tissue Kit (Qiagen, Hilden, Germany). Prior to lysis of the cells, samples were treated with $200 \mathrm{U}$ of Lyticase (Sigma-Aldrich, Taufkirchen, Germany) for $40 \mathrm{~min}$ at $30^{\circ} \mathrm{C}$. PCR amplification of the LSU was performed using the fungal specific primers NL209-NL912, as previously described (Zuccaro et al. 2003). ITS regions 
were amplified using the forward primer ITS1f (Gardes and Bruns 1993) and the reverse primers NL912 or ITS4 (White et al. 1990). For the 18S rDNA, the primers used were nu-SSU-0817 and nu-SSU-1536 (Borneman and Hartin 2000). Additionally, part of the $\beta$-tubulin gene of strain 8009 was amplified using primers BenA1 and BenA2 (Geiser et al. 1998a,b) using standard parameters. PCR products were purified with ultra clean PCR cleanup (Mo Bio Laboratories Inc.) and sequenced by AGOWA (LGC group, Berlin, Germany) or using NucleoSpin Extract II kit (Macherey-Nagel, Düren, Germany) and cloned into $p G E M-T$ vector (Promega, Madison, WI, USA). In this case, plasmid clones were isolated by the NucleoSpin Plasmid Kit (Macherey-Nagel, Düren, Germany) and sequenced with the SequiTherm EXCEL II DNA Sequencing Kit-LC (Epicentre, Madison, WI, USA) on a automated LiCor 4200 laser sequencer (LI-COR Inc., Lincoln, NE, USA).

\section{Cultivation and extraction}

For production of secondary metabolites, the fungi were cultivated at $22^{\circ} \mathrm{C}$ for 21 days on both biomalt agar (Höller et al. 2000) and barley-spelt solid-substrate media (200 g barley, $200 \mathrm{~g}$ spelt whole grain flakes, $2 \mathrm{~g}$ soy peptone, $2 \mathrm{mg} \mathrm{MnCl}_{2}, 250 \mathrm{ml}$ distilled $\mathrm{H}_{2} \mathrm{O}$ ). For initial analyses of the natural products, the cultures were lyophilized and extracted with ethyl acetate and the dried residues were defatted by petroleum extraction.

\section{Isolation of new infectopyrone derivatives from Petriella sp. (TUBS 7961)}

The methanolic extract (1024 mg) of Petriella sp. was chromatographed over a silica gel column using $\mathrm{CH}_{2} \mathrm{Cl}_{2}: \mathrm{MeOH}$ (95:5) as eluting solvent, from which 11 fractions were obtained. Fraction 7 contained dihydroinfectopyrone (Figure 1, 1, 13 mg). Compound 3 (Figure 1, 3 , $3 \mathrm{mg}$ ) was purified from fraction $11(117 \mathrm{mg})$ over a Sephadex LH-20 column using $\mathrm{CH}_{2} \mathrm{Cl}_{2}: \mathrm{MeOH}(1: 1)$ as solvent system. The second congener (Figure 1, 2) was isolated from a large-scale methanolic extract $(8 \mathrm{~g})$ that was first chromatographed by vacuum liquid chromatography over a silica gel column by gradient elution utilizing decreasing ratios of $\mathrm{CH}_{2} \mathrm{Cl}_{2}$ versus $\mathrm{MeOH}$ as the solvent system. Fraction 8 yielded compound 2 (76 mg) which was eluted with $\mathrm{CH}_{2} \mathrm{Cl}_{2}: \mathrm{MeOH}$ at a solvent ratio of $30: 70$. Purity of the compounds was monitored by reversed-phase HPLC utilizing a 35 min gradient program of $10-100 \% \mathrm{MeOH}$ in $\mathrm{H}_{2} \mathrm{O}$.

\section{Biological activities}

Cytotoxicity assay Antiproliferative activity was examined against the cell line L1578Y and was determined by an MTT assay as described earlier (Kreuter et al. 1992). L5178Y mouse lymphoma cells were grown in Eagle's minimal essential medium supplemented with $10 \%$ horse serum in roller tube culture. The cell culture media contained $100 \mathrm{U} \mathrm{ml}^{-1}$ penicillin and $100 \mu \mathrm{g} \mathrm{ml}^{-1}$<smiles>COc1cc(/C(C)=C/C(C)CC(=O)O)oc(=O)c1C</smiles><smiles>COc1cc(/C(C)=C/C(C)CC(=O)O)oc(=O)c1CO</smiles>

2<smiles>COc1cc(/C(C)=C/C(C)CCCC(=O)O)oc(=O)c1CO</smiles>

3

Figure 1 New infectopyrone derivatives 1, 2 and 3 from Petriella sp.

streptomycin and were changed twice per week. The cells were maintained in a humidified atmosphere at $37^{\circ} \mathrm{C}$ with $5 \% \mathrm{CO}_{2}$.

L1578Y was plated on a 96-multiwell plate with 50,000 cells/well. The cells were allowed to attach for $24 \mathrm{~h}$ and were then treated with different concentrations of the test samples. After this treatment, the medium was changed and the cells were incubated for $3 \mathrm{~h}$ under cell culture conditions with $20 \mathrm{\mu g} \mathrm{ml}^{-1} \mathrm{MTT}$ [3-(4,5-dimethyl-2-thiazolyl)-2,5-diphenyl-2H-tetrazolium bromide]. The conversion of the tetrazolium salt MTT to a colored formazan by mitochondrial dehydrogenases was determined as a marker of cell viability according to Mosmann (1983). After this incubation, the cells were fixed on the plate with an aqueous solution containing $1 \%$ formaldehyde and $1 \% \mathrm{CaCl}_{2}$ and then lysed with $95 \%$ isopropanol-5\% $\mathrm{HCO}_{2} \mathrm{H}$. The concentration of reduced MTT as a marker for cell viability was measured photometrically at $560 \mathrm{~nm}$. Fractions and pure compounds dissolved in dimethyl sulfoxide (DMSO) were screened at a concentration of $10 \mu \mathrm{g} /$ well.

Experiments with insects Larvae of Spodoptera littoralis (Boisduval 1833) (Noctuidae) were from a laboratory colony reared on an artificial diet under controlled conditions as described previously (Srivastava and Proksch 1991, Nugroho et al. 1999). Feeding studies were conducted with neonate larvae $(n=20)$ that were kept on an artificial diet treated with various concentrations of the compounds under study. After 6 days, survival of the larvae and weight of the surviving larvae were recorded and compared to controls. $\mathrm{ED}_{50}$ values were calculated from the dose-response curves by probit analysis. 


\section{Results and discussion}

A total of 81 fungal strains from eight sponge samples was isolated and identified according to morphology as belonging to 20 different genera (Table 1). The most frequently isolated taxa were Cladosporium spp., Penicillium spp., Petriella sp., Phialophora spp., and Engyodontium album [(Limber) de Hoog 1978]. E. album has routinely been isolated from seaweeds, suggesting a direct association with the marine environment (Zuccaro et al. unpublished data). Isolates belonging to Phialophora spp., in contrast, are frequent fungal endophytes of terrestrial plants (Schulz et al. 2006). Cladosporium and Penicillium are ubiquitous genera that are soil inhabitants, plant pathogens, and endophytes, but there are also marine isolates (e.g., Zuccaro and Mitchell 2005). Petriella spp. have, to our knowledge, not been previously reported from the marine environment.

Based on the chromatographic and mass spectrometric on-line evaluation of the fungal extracts and/or on the bioassay results, four fungi were chosen for a first detailed analysis of their natural products. These fungi were molecularly identified by BLAST analysis as Aspergillus ustus [(Bainier) Thom et Church 1926] (100\%), Penicillium sp. [highest BLAST match for Penicillium freii (Frisvad et Samson 1994) with 99\%] Petriella sp. higher BLAST match for Petriella sordida [(Zukal) Barron et Gilman 1961] with $99 \%$ and Scopulariopsis sp.

From Aspergillus ustus, TUBS 8009, two sesquiterpenes and a sesterterpene were isolated. The sesquiterpenes (Figure 2, 4 and 5) were identified as drimane derivatives based on their spectral characteristics $\left({ }^{1} \mathrm{H}\right.$ and ${ }^{13} \mathrm{C}$ NMR and MS), as well as by comparison with previously published data (Ayer and Peña-Rodriguez 1987, Hayes et al. 1996), whereas the sesterterpene (Figure 2, 6) was an ophiobolane derivative as shown by its spectral data (Cutler et al. 1984). Compound 4 is known as a

Table 1 Fungal taxa isolated from healthy (h) and diseased (d) Suberites domuncula; $\mathrm{h} / \mathrm{d}$ indicates the ratio of isolates from healthy and diseased sponge tissue.

\begin{tabular}{lll}
\hline Taxon & Number of isolates & $\mathrm{h} / \mathrm{d}$ \\
\hline Cladosporium sp. & 12 & $7 / 5$ \\
Penicillium sp. & 10 & $6 / 4$ \\
Engyodontium album & 9 & $4 / 5$ \\
Phialophora sp. & 9 & $5 / 4$ \\
Petriella sp. & 7 & $3 / 4$ \\
Exophiala sp. & 5 & $2 / 2$ \\
Unidentified & 4 & $3 / 1$ \\
Acremonium sp. & 3 & $2 / 1$ \\
Paecilomyces sp. & 2 & $1 / 1$ \\
Sporobolomyces sp. & 2 & $1 / 1$ \\
Trichoderma sp. & 2 & $1 / 1$ \\
Aspergillus ustus & 1 & $\mathrm{~h}$ \\
Chaetomium $\mathrm{sp}$. & 1 & $\mathrm{~h}$ \\
Fusarium sp. & 1 & $\mathrm{~h}$ \\
Gliomastix sp. & 1 & $\mathrm{~h}$ \\
Nodulisporium sp. & 1 & $\mathrm{~h}$ \\
Phoma sp. & 1 & $\mathrm{~h}$ \\
Scopulariopsis sp. & 1 & $\mathrm{~d}$ \\
Stemphylium $\mathrm{sp}$. & 1 & $\mathrm{~d}$ \\
Stilbella sp. & 1 & $\mathrm{~h}$ \\
Tolypocladium $\mathrm{sp}$. & 1 & $\mathrm{~h}$ \\
Mycelia sterila & 6 & $4 / 2$ \\
\hline
\end{tabular}<smiles>C/C=C/C=C/C=C/C(=O)O[C@H]1C=C2COC(=O)[C@]2(O)[C@@]2(C)CCCC(C)(C)[C@@]12C</smiles>

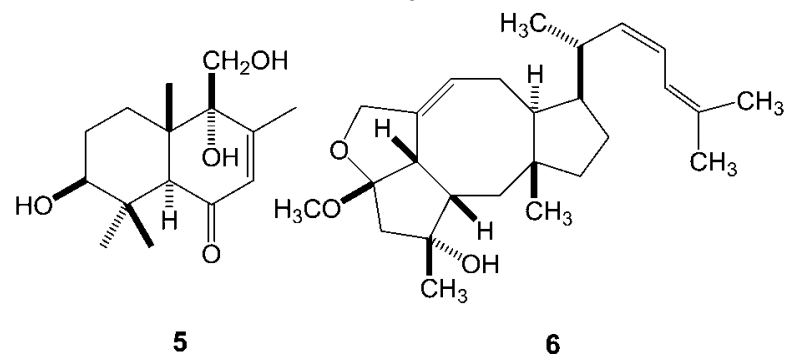

Figure 2 Terpenoid metabolites 4, 5 and $\mathbf{6}$ from Aspergillus ustus.

metabolite from $A$. ustus var. pseudoreflectus Kozak 1989 isolated from a soil sample (Hayes et al. 1996). Compound 5, also known as deoxyuvidin, was reported previously from Alternaria brassicae [(Berk.) Sacc. 1880], which is a pathogen on canola (Ayer and Peña-Rodriguez 1987). The ophiobolane derivative 6 that is known under the trivial name ophiobolin $\mathrm{H}$ was previously isolated from a terrestrial isolate of $A$. ustus obtained from seeds of Pisum sativum L. (Cutler et al. 1984). Finding some of the same metabolites in isolates of a given taxon from completely divergent habitats is a frequent phenomenon, e.g., coniothyromycins were produced by endophytic isolates of Coniothyrium palmarum (Corda 1840) from Lower Saxony, but also from Coniothyrium sp. isolated from Borneo soil samples (Krohn et al. 1994a,b).

The crude organic extract obtained from Aspergillus ustus analyzed in this study had strong cytotoxic activity when tested in vitro against the murine cancer cell line L5178Y at a concentration of $10 \mu \mathrm{g} \mathrm{ml}^{-1}$. This activity was traced to the drimane derivative 4 , which exhibited an $\mathrm{ED}_{50}$ value of $1.9 \mu \mathrm{g} \mathrm{ml}^{-1}$ against the L5178Y cell line. When tested against other cell lines, such as PC12 or HeLa, it proved inactive up to a concentration of 10 $\mu \mathrm{g} \mathrm{ml}^{-1}$, thus indicating selectivity against lymphoma cell lines. Compounds 5 and $\mathbf{6}$ showed no activity against any of the cell lines tested at least up to a dose of 10 $\mu \mathrm{g} \mathrm{ml}^{-1}$. Ongoing investigation of the extract derived from $A$. ustus suggests the presence of further terpenoid derivatives that are presently under investigation.

Similar to the extract of Aspergillus ustus, the extract of the second sponge-associated fungus, Petriella sp., exhibited strong cytotoxicity when tested against the L5178Y cell line and was therefore chosen for a detailed analysis of its secondary metabolites. Bioassay-guided isolation yielded a cyclic tetrapeptide (Figure 3,7 ) with a molecular weight of 568 as a prominent and strongly active component of the fungal extract. Spectroscopic analysis proved that compound 7 was the known WF3161 previously reported as a component of the culture filtrate of Petriella guttulata (Barron et Cain 1961) isolated from a soil sample collected in Japan (Umehara et al. 


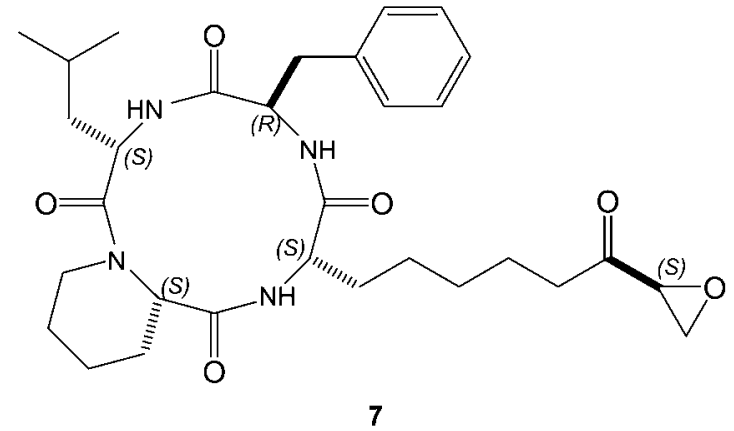

Figure 3 Cyclic tetrapeptide 7 isolated from Petriella sp.

1983). The amino acid sequence of the peptide is cyclo(L-Leu-L-Pip-L-Aoe-D-Phe), where Pip represents pipecolic acid and Aoe represents the unusual amino acid 2-amino-8-oxo-9,10-eoxydecanoic acid, which is in congruence with the published data (Kawai et al. 1986). Compound $\mathbf{7}$ exhibited exceptionally strong activity against the L5178Y cell line, with an $\mathrm{ED}_{50}$ value $<0.1$ $\mu \mathrm{g} \mathrm{ml}^{-1}$. This is again in congruence with previous studies that demonstrated in vivo activity of this peptide. When mice that had been inoculated intraperitoneally with lymphocytic leukemia P-388 cells were treated $24 \mathrm{~h}$ later by intraperitoneal administration of compound 7, a prolongation of the survival time occurred (Umehara et al. 1983). The treated over control (T/C) (\%) value increased (dose dependent) from 133 (dose of $12.5 \mathrm{mg} \mathrm{kg}^{-1} \mathrm{~d}^{-1}$ ) to 175 (dose of $100 \mathrm{mg} \mathrm{kg}^{-1} \mathrm{~d}^{-1}$ ).

In addition to the tetrapeptide 7, further compounds exhibiting cytotoxicity were isolated from the extract of Petriella sp. The compound showing the strongest activity after peptide 7 proved to be a new natural product (1). In the HR-ESIMS, 1 exhibited a pseudomolecular ion at $\mathrm{m} / \mathrm{z} 267.1220$, which was consistent with a molecular formula of $\mathrm{C}_{14} \mathrm{H}_{19} \mathrm{O}_{5}$ for its $[\mathrm{M}+\mathrm{H}]^{+}$(calc, 267.1227) $\left([\alpha]_{D}^{20}=-3.2, c=1.0, \mathrm{MeOH}\right)$.

From the multiplicities observed in the ${ }^{1} \mathrm{H}$ NMR spectrum of 1 (Table 2), as well as corresponding cross signals in the COSY spectrum, the presence of the side chain comprising $\mathrm{H}_{2}-2$ ( $\delta 2.42$ and 2.35), $\mathrm{H}-3$ ( $\delta 3.13$ ), $3-\mathrm{CH}_{3}(\delta 1.12)$, as well as $\mathrm{H}-4$ ( $\left.\delta 6.38\right)$, could easily be derived. The $\mathrm{HMBC}$ correlations from $\mathrm{H}_{2}-2$ and $\mathrm{H}-3$ to a carbon resonating at $\delta 175.5(\mathrm{C}-1)$ suggested that the terminus of this side chain was a free carboxylic acid. On the other hand, $\mathrm{HMBC}$ correlations from $\mathrm{H}-4$ to $\mathrm{C}-5$ ( $\delta 127.1)$, as well as $5-\mathrm{CH}_{3}(\delta 12.4)$, established the presence of a methyl-bearing carbon as part of a double bond with the protonated C-4 $(\delta 139.5)$ at the other end of the side chain in 1. The 4-methoxy- $\alpha$-pyrone moiety in 1 was evident from the $\mathrm{HMBC}$ correlations observed for the two methyl groups $4^{\prime}-\mathrm{OCH}_{3},\left(\delta 3.98\right.$, to $\mathrm{C}-4^{\prime}, \delta$ 168.7) and $3^{\prime}-\mathrm{CH}_{3}\left(\delta 1.88\right.$, to $\mathrm{C}-4^{\prime}, \mathrm{C}^{\prime} 2^{\prime}$, and $\mathrm{C}-3^{\prime}, \delta 167.1$ and 102.0 , respectively), as well as $\mathrm{H}^{-5} 5^{\prime}$ ( $\delta 6.49$, to $\mathrm{C}-3^{\prime}$, C-4', and C-6', $\delta$ 161.2). Finally, the connection of the two substructures at C-5 and C-6' was established through $\mathrm{HMBC}$ correlations of $\mathrm{H}-5^{\prime}$ to $\mathrm{C}-5$, as well as $\mathrm{H}-4$ to $\mathrm{C}-6^{\prime}$. Thus, 1 was identified as the 2,3-dihydro derivative of infectopyrone, which had been isolated previously from Alternaria infectoria Simmons 1986, a plant pathogenic fungal strain frequently causing infec- tions of cereals and other food products (Larsen et al. 2003). Dihydroinfectopyrone (1) exhibited an $E_{50}$ value of $0.2 \mu \mathrm{g} \mathrm{ml}^{-1}$ when tested against the L5178Y cell line.

Compound 2 had a molecular weight 16 amu higher than that of dihydroinfectopyrone (1), suggesting that it is an oxygenated congener. This was corroborated by the HR-ESIMS, showing a pseudomolecular ion at $\mathrm{m} / \mathrm{z}$ 283.1170, which was consistent with a molecular formula of $\mathrm{C}_{14} \mathrm{H}_{19} \mathrm{O}_{6}$ for its $[\mathrm{M}+\mathrm{H}]^{+}$(calc, 283.1176) $\left([\alpha]_{\mathrm{D}}{ }^{20}=-60.6\right.$, $\mathrm{C}=0.5, \mathrm{MeOH}$ ).

Correspondingly, in the ${ }^{1} \mathrm{H}$ and ${ }^{13} \mathrm{C}$ NMR data obtained for 2 (Table 2), the signal attributed to $3^{\prime}-\mathrm{Me}$ in $\mathbf{1}$ was missing, and instead, chemical shifts characteristic of a hydroxymethyl functionality were observed $\left(\delta_{\mathrm{H}} 4.44,2 \mathrm{H}\right.$, and $\left.\delta_{\mathrm{C}} 53.8\right)$, while the remaining signals and correlations observed in the HMBC spectrum of 2 were almost identical to the corresponding ones obtained for $\mathbf{1}$. Thus, 2 was identified as the $3^{\prime}$-demethyl-3'-hydroxymethyl derivative of dihydroinfectopyrone.

Initially, the structural elucidation of the remaining infectopyrone-derived congener $\mathbf{3}$ was hampered by the small amounts isolated and the fact that, due to the limited supply of the compound, it was not possible to achieve complete purification, rendering the quality of the NMR spectra rather poor in comparison to those measured for $\mathbf{1}$ or $\mathbf{2}$. However, close comparison with the spectral data of the previous derivatives resulted in the deduction that $\mathbf{3}$ was a dihomo congener of $\mathbf{2}$, differing by insertion of two additional methylene groups in the side chain next to the carboxylic acid function. This was in agreement with the HR-ESIMS, which confirmed the molecular formula as $\mathrm{C}_{16} \mathrm{H}_{22} \mathrm{O}_{6}$, again derived by a corresponding pseudomolecular ion at $\mathrm{m} / \mathrm{z} 333.130$ $\left([\mathrm{M}+\mathrm{Na}]^{+} \quad \mathrm{C}_{16} \mathrm{H}_{22} \mathrm{NaO}_{6}\right.$, calc. 333.1309) $\left([\alpha]_{\mathrm{D}}^{20}=-17\right.$, $\mathrm{c}=0.1, \mathrm{MeOH})$. The position of the two additional $\mathrm{CH}_{2}$ units was established from the COSY spectrum, which revealed a common spin system comprising $\mathrm{H}_{2}-2, \mathrm{H}_{2}-3$, $\mathrm{H}_{2}-4, \mathrm{H}-5, \mathrm{H}-6$ and $5-\mathrm{CH}_{3}$, as well as $7-\mathrm{CH}_{3}$. Further evidence was provided by the HMBC spectrum, which in addition to supporting the said spin system also revealed the connection of $\mathrm{C}-2$ to a free carboxylic acid function $(\mathrm{C}-1)$, and the attachment of the pyrone ring through C- 6 ' and C-7. Key correlations included both $\mathrm{H}_{2}-2$ and $\mathrm{H}_{2}-3$ with $\mathrm{C}-1$, as well as $7-\mathrm{CH}_{3}$ with $\mathrm{C}-6^{\prime}$ (Table 2). When tested for cytotoxic properties under experimental conditions similar to those employed for $\mathbf{1}$, both $\mathbf{2}$ and $\mathbf{3}$ showed almost no activity.

Penicillium sp., TUBS 7979, was selected for further analysis based on the marked growth inhibitory activity (when tested at a dose of 1000 ppm incorporated into artificial diet) of its crude organic extract against larvae of Spodoptera littoralis. In total, 10 different known compounds, including viridicatin (Figure 4, 8) (Cunningham and Freeman 1953), its hydroxylated analog viridicatol (Figure 4, 9) (Birkinshaw et al. 1963), cyclopenin (Figure $4,10)$ (Bracken et al. 1954), its hydroxyl derivative cyclopenol (Figure 4, 11) (Hodge et al. 1988), emodin (Figure 4,12 ) (Cohen and Towers 1995), physcion (Figure 4, 13) (Anke et al. 1980), the methylated chrysophanol derivative (Figure 4, 14) (Thomson et al. 1987), the acetophenone derivative clavatol (Figure 4, 15) (Gatenbeck and Brunsberg 1966) and citrinin (Figure 4, 16) (Barber et al. 


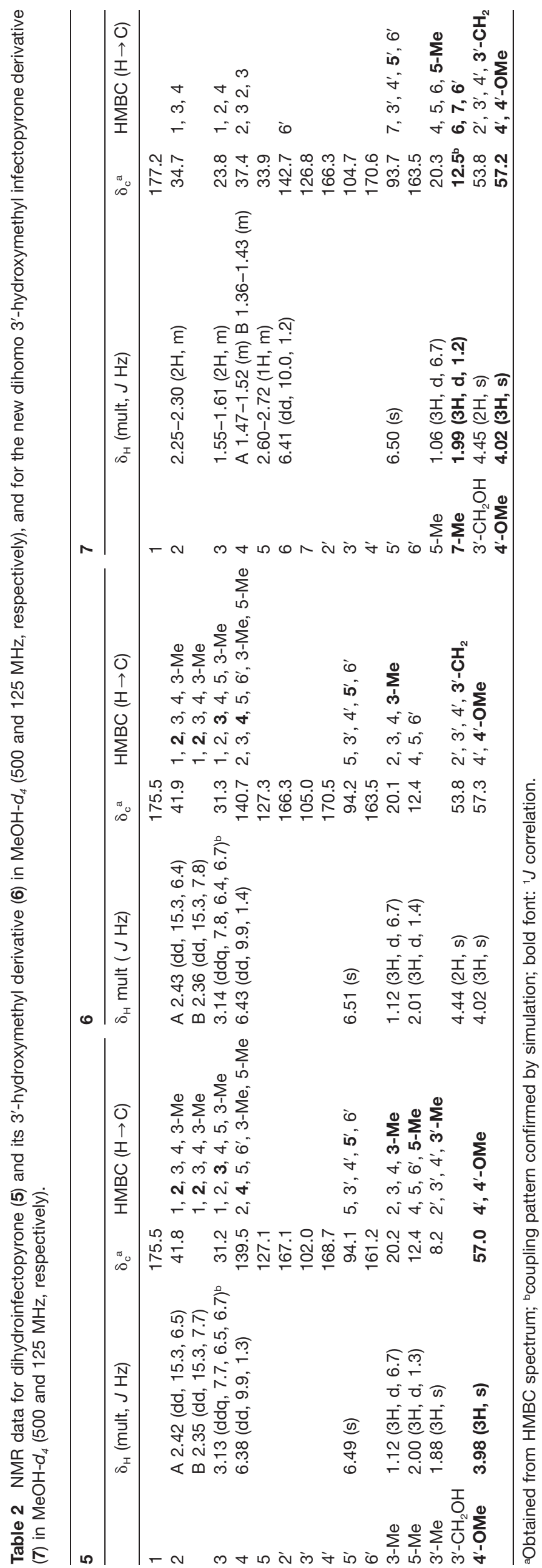


<smiles>[R]c1cccc(-c2c(O)c(=O)[nH]c3ccccc23)c1</smiles><smiles>[R]c1cccc([C@@H]2O[C@]23C(=O)Nc2ccccc2C(=O)N3C)c1</smiles>

10: $\mathrm{R}=\mathrm{H}$ 11: $\mathrm{R}=\mathrm{OH}$

8: $R=H$ 9: $\mathrm{R}=\mathrm{OH}$<smiles>[R]c1cc(OCC)c2c(c1)C(=O)c1cc(C)cc(O)c1C2=O</smiles>

12: $\mathrm{R}_{1}=\mathrm{H} ; \mathrm{R}_{2}=\mathrm{OH}$ 14: $\mathrm{R}_{1}=\mathrm{CH}_{3} ; \mathrm{R}_{2}=\mathrm{H}$<smiles>CC(=O)c1cc(C)c(O)c(C)c1O</smiles>

15<smiles>COc1cc(O)c2c(c1)C(C1c3cc(C)cc(O)c3C(=O)c3c(OC)cc(OC)cc31)c1cc(C)cc(O)c1C2=O</smiles>

13<smiles>CC1C(=O)C(C(=O)O)=C(O)C2=CO[C@H](C)[C@H](C)C21</smiles>

16
Figure 4 Metabolites 8-16 derived from Penicillium sp.

1987) were isolated and identified. The growth inhibitory activity of the extract against $S$. littoralis larvae was traced mainly to viridicatin (8), viridicatol (9), cyclopenin (10) and cyclopenol (11). All four compounds clearly suppressed larval growth at an arbitrarily chosen concentration of $237 \mathrm{ppm}$ when compared to controls (Figure 5). Viridicatol (9), which differs from viridicatin (8) only by one hydroxyl substituent, was by far the most active compound encountered and had an $\mathrm{EC}_{50}$ value of ca. $50 \mathrm{ppm}$ (Figure 6). The larval growth inhibitory activities of compounds 8-11 are reported here for the first time.

The fourth fungal strain, TUBS 8017 , selected for an investigation of the produced natural products, belonged to the genus Scopulariopsis. From this strain, three dif- ferent natural products were isolated, which included the rather frequently occurring cladosporin (Figure 7, 17) (Reese et al. 1988), and also the structurally unusual tetramic acid derivatives quinolactacin A1 (Figure 7, 18) (Kim et al. 2001) and A2 (Figure 7, 19) (Kim et al. 2001). The latter two compounds were previously isolated from the genus Penicillium and have recently aroused interest due to their inhibitory activity against TNF- $\alpha$ production by macrophages that had been stimulated by LPS (Kakinuma et al. 2000), as well as their inhibitory activity against acetylcholinesterase (Kim et al. 2001). While TNF- $\alpha$ is involved in inflammations and may even lead to septic shock, acetylcholinesterases are interesting drug targets for the treatment of neurodegenerative disorders, such as Alzheimer's disease. The naturally occurring ACE inhibitor galanthamin from Galanthus spp. is in clinical use for this indication. There is hope that the quinolactacins may prove to be further drug candidates for the treatment of this disease.

\section{Conclusion}

These investigations are the initial report on a larger study (using molecular and classical cultivation methods) on the fungal diversity and chemical productivity of spongederived fungi associated with the Mediterranean sponge Suberites domuncula. As can be seen in Table 1, specimens of $S$. domuncula that were kept in aquaria yielded a relatively high diversity of fungi, including numerous ubiquitous taxa, e.g., Aspergillus, Penicillium and Cladosporium, which have repeatedly been isolated from sponges in the past (Höller et al. 2000, Ebel 2006), but also Engyodontium album and Petriella sp. that have not been previously reported from sponges. Fungi are probably not responsible for diseases of aquarium-grown S. domuncula. However, this should be verified with diseased and healthy wild samples.

Chemical investigations of cultivable fungi are the second goal of this project. Even though to date only four fungal taxa obtained from Suberites domuncula have been chemically investigated, the number of secondary metabolites obtained (19) and the chemical diversity of these compounds, which include terpenoids (4-6), alka-

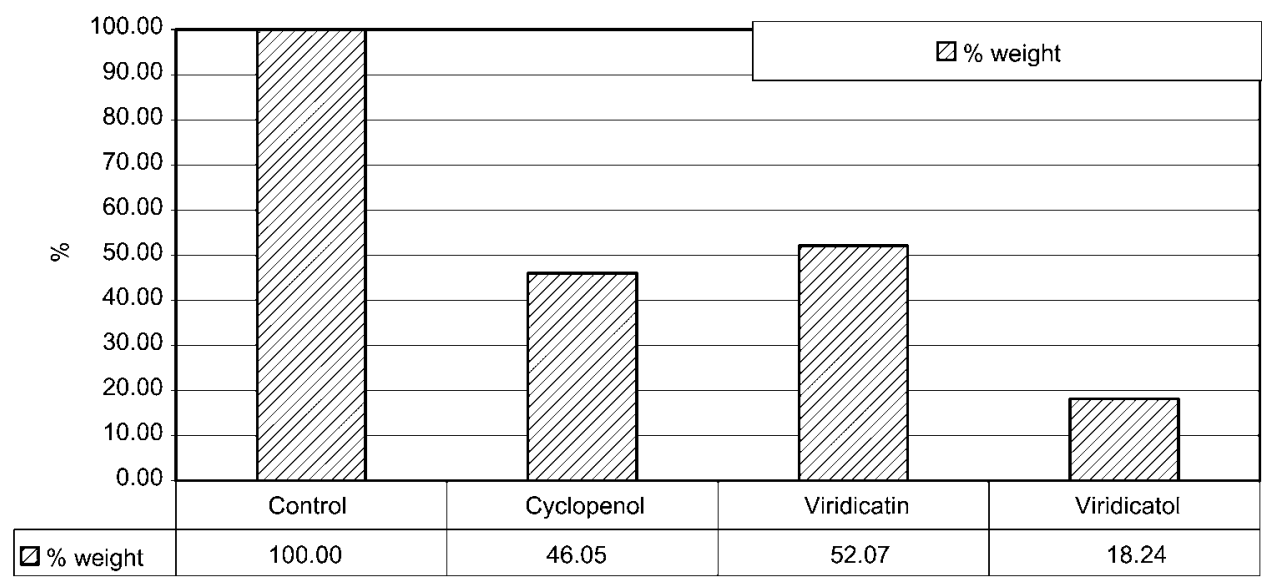

Figure 5 Growth inhibitory activities of cyclopenol 11, viridicatin 8 and viridicatol 9 against Spodoptera littoralis at an arbitrarily chosen concentration of $237 \mathrm{ppm}$. 


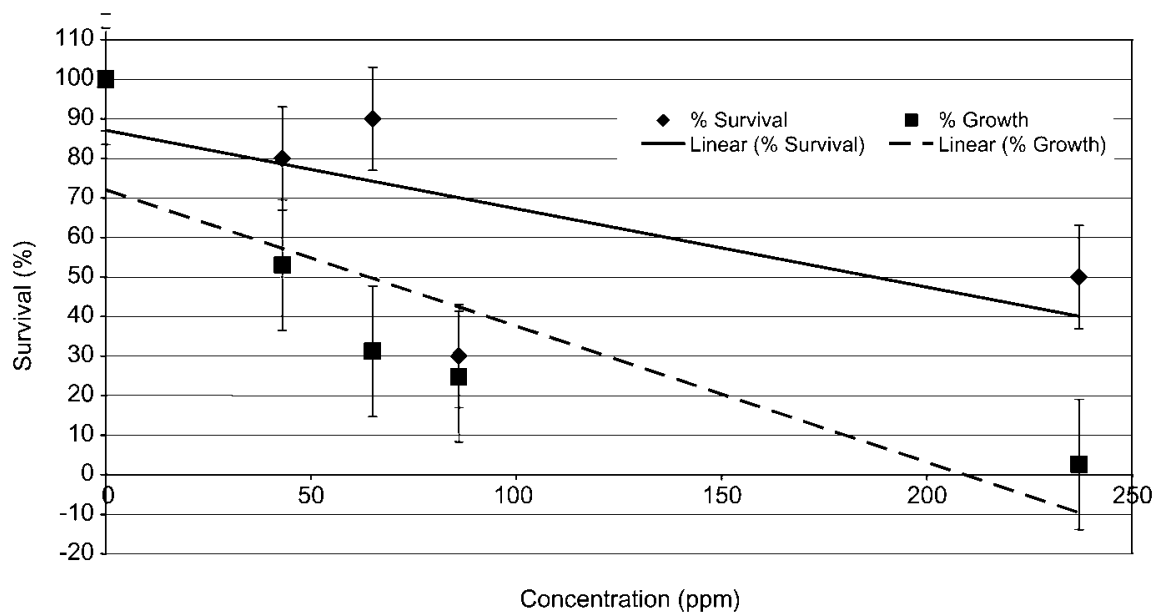

Figure 6 Viridicatol in the feeding assay of Spodoptera littoralis.<smiles>C[C@H]1CCC[C@@H](C[C@@H]2Cc3cc(O)cc(O)c3C(=O)O2)O1</smiles>

17<smiles>CC[C@H](C)[C@H]1NC(=O)c2c1n(C)c1ccccc1c2=O</smiles>

18<smiles>CC[C@H](C)[C@H]1NC(=O)c2c1n(C)c1ccccc1c2=O</smiles>

19
Figure 7 Compounds 17, 18 and 19 obtained from Scopulariopsis sp.

loids $(\mathbf{8}-11,18,19)$, polyketides $(1-3,12-17)$ and peptides (7) are impressive, especially when viewed against their host $S$. domuncula. While sponges in general are the most prolific marine invertebrates in terms of natural products (Blunt et al. 2007), S. domuncula has so far yielded only three secondary metabolites (MarinLit 2006) and is thus among the chemically poorer sponges. Fungal isolates clearly surpass their host in terms of chemical diversity, as shown in this study for only four taxa out of more than 20 fungal strains isolated so far. It is tempting to speculate that the diversity of fungi isolated from $S$. domuncula, as well as their metabolic productiveness, is largely a result of the paucity of active metabolites produced by the host. However, we must first determine which of the fungi are actually associated and are not simply spores trapped by sponge filtration. Only molecular analyses will answer this question.

Based on these first results, we expect in the near future to increase the list of structurally unusual bioactive metabolites when the remaining fungi have been analyzed (Table 1). We intend to identify and compare fungal strains that are amenable to culturing conditions to those that are likewise present in the sponge, but can only be identified using molecular methods, such as ITS sequences (Zuccaro et al. 2003, Bugni and Ireland 2004,
Ebel 2006), in order to obtain a clearer picture of the fungal diversity in relation to various factors, such as locality within the Mediterranean Sea, season and the influence of controlled conditions (in aquaria vs. the wild). Additionally, we will study the secondary metabolites that these fungi produce, as they may play important roles in situ.

\section{Acknowledgements}

This study was supported by a grant from BMBF to the Center of Excellence BIOTECMarin and the grant "Gesundheitszustand mariner Ökosysteme: Immunkompetenz aquatischer Invertebraten als neues Target für das Biomonitoring und Bioprospecting (Inhibitoren von Immunophilinen)", as well as by a scholarship of DAAD/MOST for Xiang Li. We thank Kathrin Meier and Tanja Piekarski for excellent technical assistance.

\section{References}

Abraham, E.P. and P.B. Loder. 1972. In: (E.H. Flynn, ed.) Cephalosporins and penicillins; chemistry and biology. Academic Press, New York. pp. 1-26.

Alker, A.P., G.W. Smith and K. Kim. 2001. Characterisation of Aspergillus sydowii (Thom et Church), a fungal pathogen of Caribbean sea fan corals. Hydrobiologia 460: 105-111.

Anke, H., I. Kolthoum, H. Zähner and H. Laatsch. 1980. Metabolic products of microorganisms. 185. The anthraquinones of the Aspergillus glaucus group. I. Occurrence, isolation, identification and antimicrobial activity. Arch. Microbiol. 126: 223-230.

Ayer, W.A. and L.M. Peña-Rodriguez. 1987. Metabolites produced by Alternaria brassicae, the black spot pathogen of canola. Part 2. Sesquiterpenoid metabolites. J. Nat. Prod. 50: 408-417.

Barber, J., J.L. Cornford, T.D. Howard and D. Sharples. 1987. The structure of citrinin in vivo. J. Chem. Soc., Perkin Trans. 1: 2743-2744.

Birkinshaw, J.H., M. Luckner, Y.S. Mohammed, K. Mothes and C.E. Stickings. 1963. Studies in biochemistry of microorganisms. 114. Viridicatol and cyclopenol, metabolites from Penicillium viridicatum Westling and Penicillium cyclopium Westling. Biochem. J. 89: 196-202.

Blunt, J.W., B.R. Copp, W.P. Hu, M.H. Munro, P.T. Northcote and M.R. Prinsep. 2007. Marine natural products. Nat. Prod. Rep. 24: 31-86. 
Borneman, J. and R.J. Hartin. 2000. PCR primers that amplify fungal rRNA genes from environmental samples. Appl. Environ. Microbiol. 66: 4356-4360.

Bracken, A., A. Pocker and H. Raistrick. 1954. Studies in the biochemistry of microorganisms. 93. Cyclopenin, a nitrogencontaining metabolic product of Penicillium cyclopium Westling. Biochem. J. 57: 587-595.

Bugni, T.S. and C.M. Ireland. 2004. Marine-derived fungi: a chemically and biologically diverse group of microorganisms. Nat. Prod. Rep. 21: 143-163.

Butzke, D. and J. Piel. 2006. Genomic and metagenomic strategies to identify biosynthetic gene clusters in uncultivated symbionts of marine invertebrates. In: (P. Proksch and W.E.G. Müller, eds) Frontiers in marine biotechnology. Horizon Bioscience, Norfolk. pp. 327-356.

Cohen, P.A. and G.H.N. Towers. 1995. Anthraquinones and phenanthroperylenequinones from Nephroma laevigatum. J. Nat. Prod. 58: 520-526.

Cunningham, K.G. and G.G. Freeman. 1953. The isolation and some chemical properties of viridicatin, a metabolic product of Penicillium viridicatum Westling. Biochem. J. 53: 328-332.

Cutler, H.G., F.G. Crumley, R.H. Cox, J.P. Springer, R.F. Arrendale, R.J. Cole and P.D. Cole. 1984. Ophiobolins G and H: new fungal metabolites from a novel source, Aspergillus ustus. J. Agric. Food Chem. 32: 778-782.

Duncan, R.A. Jr, R. Sullivan, S.C. Alderman, J.W. Spatafora and J.F. White Jr. 2002. Claviceps purpurea var. spartinae var. nov.: an ergot adapted to the aquatic environment. Mycotaxonomy 81: 11-25.

Ebel, R. 2006. Secondary metabolites from marine-derived fungi. In: (P. Proksch and W.E.G. Müller, eds) Frontiers in marine biotechnology. Horizon Bioscience, Norfolk. pp. 73-144.

Gardes, M. and T.D. Bruns. 1993. ITS primers with enhanced specificity for basidiomycetes: application to the identification of mycorrhizae and rusts. Mol. Ecol. 2: 113-118.

Gatenbeck, S. and U. Brunsberg. 1966. The mechanism of clavatol formation in Aspergillus clavatus. Acta Chem. Scand. 20: 2334-2338

Geiser, D.M., J.W. Taylor, K.B. Ritchie and W.G. Smith. 1998a. Cause of sea fan death in the West Indies. Nature 394: 137-138.

Geiser D.M., J.C. Frisvad and J.W. Taylor. 1998b. Evolutionary relationships in Aspergillus section Fumigati inferred from partial-tubulin and hydrophobin DNA sequences. Mycologia 90: 831-845.

Hayes M.A., S.K. Wrigley, I. Chetland, E.E. Reynolds, A.M. Ainsworth, D.V. Renno, M.A. Latif, X.M. Cheng, D.J. Hupe, P. Charlton and A.M. Doherty. 1996. Novel drimane sesquiterpene esters from Aspergillus ustus var. pseudodeflectus with endothelin receptor binding activity. J. Antibiot. 49: 505-512.

Hodge, R.P., C.M. Harris and T.M. Harris. 1988. Verrucofortine, a major metabolite of Penicillium verrucosum var. cyclopium, the fugus that produces the mycotoxin verrucosidin. J. Nat. Prod. 51: 66-73.

Höller, U., A.D. Wright, G.F. Matthee, G.M. König, S. Draeger, H.-J. Aust and B. Schulz. 2000. Fungi from marine sponges: diversity, biological activity and secondary metabolites. Mycol. Soc. Phytochem. 104: 1354-1365.

Jensen, P.R. and W. Fenical. 2002. Secondary metabolites from marine fungi. In: (K.D. Hyde, ed.) Fungi in marine environments. Fungal Diversity Research Series 7. Fungal Diversity Press, Hong Kong. pp. 293-315.

Kakinuma, N., H. Iwai, S. Takahashi, K. Hamano, T. Yanagisawa, K. Nagai, K. Tanaka, K. Suzuki, F. Kirikae, T. Kirikae and A. Nakagawa. 2000. Quinolactacins A, B and C: novel quinolone compounds from Penicillium sp. EPF-6. I. Taxonomy, production, isolation and biological properties. J. Antibiot. 53: 1247-1251.

Kawai, M., R.S. Pottorf and D.H. Rich. 1986. Structure and solution conformation of the cytostatic cyclic tetrapeptide WF-3161, cyclo[L-leucyl-L-pipecolyl-L-(2-amino-8-oxo-9,10-
epoxydecanoyl)-D-phenylalanyl]. J. Med. Chem. 29: 24092411.

Kim, W.G., N.K. Song and I.D. Yoo. 2001. Quinolactacins A1 and $\mathrm{A} 2$, new acetylcholinesterase inhibitors from Penicillium citrinum. J. Antibiot. 54: 831-835.

Kohlmeyer, J. and B. Volkmann-Kohlmeyer. 2003. Fungi from coral reefs: a commentary. Mycol. Res. 107: 386-387.

König, G.M., S. Kehraus, S.F. Seibert, A. Abdel-Lateff and D. Müller. 2006. Natural products from marine organisms and their associated microbes. ChemBioNews 7: 229-238.

Kreuter, M.H., A. Robitzki, S. Chang, R. Steffen, M. Michaelis, Z. Kljajic, M. Bachmann, H.C. Schröder and W.E.G. Müller. 1992. Production of the cytostatic agent aeroplysinin by the sponge Verongia aerophoba in in vitro culture. Comp. Biochem. Physiol. 101C: 183-187.

Krohn, K., A. Michel, U. Flörke, H.-J. Aust, S. Draeger and B. Schulz. 1994a. Palmarumycins $\mathrm{CP}_{1}-\mathrm{CP}_{4}$ from Coniothyrium palmarum: isolation, structure elucidation and biological activity. Liebigs Ann. Chem. 1994: 1093-1097.

Krohn, K., A. Michel, U. Flörke, H.-J. Aust, S. Draeger and B. Schulz. 1994b. Palmarumycins $\mathrm{C}_{1}-\mathrm{C}_{16}$ from Coniothyrium sp.: isolation, structure elucidation and biological activity. Liebigs Ann. Chem. 1994: 1099-1108.

Laatsch, H. 2006. Marine bacterial metabolites. In: (P. Proksch and W.E.G. Müller, eds) Frontiers in marine biotechnology. Horizon Bioscience, Norfolk. pp. 225-288.

Larsen, T.O., N.B. Perry, B. Andersen. 2003. Infectopyrone, a potential mycotoxin from Alternaria infectoria. Tetrahedron Lett. 44: 4511-4513.

LePennec, G., S. Perović, M.S.A. Ammar, V.A. Grebenjuk, R. Steffen and W.E.G. Müller. 2003. Cultivation of primmorphs from the marine sponge Suberites domuncula: morphogenetic potential of silicon and iron. J. Biotechnol. 100: 93-108.

MarinLit, Version September 2006. A marine literature database produced and maintained by the Department of Chemistry, University of Canterbury, New Zealand. Available at: http:// www.chem.canterbury.ac.nz/marinlit/marinlit.shtml.

Mosmann, T. 1983. Rapid colorimetric assay for cellular growth and survival: application to proliferation and cytotoxicity assays. J. Immunol. Methods 65: 55-63.

Nugroho B.W., R.A. Edrada, V. Wray, L. Witte, G. Bringmann, M. Gehling and P. Proksch. 1999. An insecticidal rocaglamide derivative and related compounds from Aglaia odorata (Meliaceae). Phytochemistry 51: 367-376.

Perović-Ottstadt, S., T. Adell, P. Proksch, M. Wiens, M. Korzhev, V. Gamulin and W.E.G. Müller. 2004. A $(1 \rightarrow 3)-$ D glucan recognition protein from the sponge Suberites domuncula. J. Eur. Biochem. 271: 1924-1937.

Proksch, P., R.A. Edrada and R. Ebel. 2002. Drugs from the seas - current status and microbiological implications. Appl. Microbiol. Biotech. 59: 125-134.

Ramaswamy, A.V., P.M. Flatt, D.J. Edwards, T.L. Simmons, B. Han and W.H. Gerwick. 2006. The secondary metabolites and biosynthetic gene clusters of marine cyanobacteria. Applications in biotechnology. In: (P. Proksch and W.E.G. Müller, eds) Frontiers in marine biotechnology. Horizon Bioscience, Norfolk. pp. 175-224.

Reese, P.B., B.J. Rawlings, S.E. Ramer and J.C. Vederas. 1988. Comparison of stereochemistry of fatty acid and cladosporin biosynthesis in Cladosporium cladosporioides using ${ }^{2} \mathrm{H}$ decoupled ${ }^{1} \mathrm{H},{ }^{13} \mathrm{C}$ NMR shift correlation. J. Am. Chem. Soc. 110: 316-318.

Schulz, B., C. Boyle and T. Sieber, eds. 2006. Microbial root endophytes. Springer Verlag, Berlin. pp. 367.

Shimizu, Y. and B. Li. 2006. Microalgae as a source of bioactive molecules: special problems and methodology. In: (P. Proksch and W.E.G. Müller, eds) Frontiers in marine biotechnology. Horizon Bioscience, Norfolk. pp. 145-176.

Srivastava, R.P. and P. Proksch. 1991. Contact toxicity and feeding inhibitory activity of chromenes from Asteraceae against Spodoptera littoralis (Lepidoptera: Noctuidae). Entomol. Gener. 15: 265-274. 
Thomson, R.H. 1987. Naturally occurring quinines III. Recent advances. Chapman \& Hall, New York. pp. 219-223.

Umehara, K., K. Nakahara, S. Kiyoto, M. Iwami, M. Okamoto, H. Tanaka, M. Kohsaka, H. Aoki and H. Imanaka. 1983. Studies on WF-3161, a new antitumor antibiotic. J. Antibiot. 36: 478-483.

White, T.J., T.D. Bruns, S. Lee and J. Taylor. 1990. Analysis of phylogenetic relationships by amplification and direct sequencing of ribosomal RNA genes. In: (M.A. Innis, D.H. Gelfand, J.J. Sninsky and T.J. White, eds) PCR protocols: a guide to methods and applications. Academic Press, New York. pp. 315-322.

Zuccaro, A. and J.I. Mitchell. 2005. Fungal communities of sea- weeds. In: (J. Dighton, J.F. White Jr. and P. Oudemans, eds) The fungal community, 3rd ed. CRC Press, New York. pp. 533-579.

Zuccaro, A., B. Schulz and J.I. Mitchell. 2003. Molecular detection of ascomycetes associated with Fucus serratus. Mycol. Res. 107: 1451-1466.

Zuccaro, A., R.C. Summerbell, W. Gams, H.J. Schroers and J.I. Mitchell. 2004. A new Acremonium species associated with Fucus spp., and its affinity with a phylogenetically distinct marine Emericellopsis clade. Stud. Mycol. 50: 283-297.

Received 19 June, 2007; accepted 21 January, 2008; online first March 7, 2008 